\title{
Kolme aikuiskasvatuksen konferenssia
}

Suomen Akatemian tutkimusassistenttina minulle tarjoutui mahdollisuus osallistua Calgaryssa, Kanadassa järjestettyihin kolmeen aikuiskasvatuksen konferenssiin toukokuussa 1988. Kaikki kolme konferenssia olivat suhteellisen laajoja ja useammista samanaikaisista esityksistä koostuvia, joten seuraava katsaus perustuu lähinnä valikoivaan osallistumiseeni ja lukuisiin käytäväkeskusteluihin, jotka ovat ilmeisesti aina konferenssien tärkein anti.

\section{Participatory Research Workshop}

Participatory Research Workshop järjestettiin 3. toukokuuta ja siihen osallistui 80 tutkijaa ja käytännön aikuiskasvattajaa pääosin Kanadasta, mutta myös Nicaraguasta, Englannista, Yhdysvalloista ja Suomesta. Osanottajamäärä oli rajoitettu kahdeksaankymmeneen, joten muutama kymmenen muuta halukasta jouduttiin sulkemaan ulkopuolelle.

Workshopin tavoitteena oli selkeyttää osallistuvan tutkimuksen (participatory research) tarkoitusta ja olemusta, luoda perustaa kansainvälisen verkoston toiminnalle (networking) ja yhteiselle resurssien identifioimiselle, jäsentää osallistuvan ja perinteisen tutkimuksen ja koulutuksen tehtäviä, sekä suunnitella vuonna 1989 järjestettävää kansainvälistä konferenssia.

Workshop koostui kolmesta paneelista ja niiden puitteissa pide- tyistä esityksistä sekä pienryhmätyöskentelystä, jossa osallistavan tutkimuksen eri puolia tarkasteltiin keskustellen. Ensimmäinen paneeli käsitteli osallistumisen välttämättömyyttä. Paneelin puhujista pääsiht. Budd Hall (International Council for Adult Education, ICAE) tarkasteli osallistavan tutkimuksen historiaa ja oletuksia.

Hän korosti osallistavan tutkimuksen - merkitystä teoreettisen tiedostamisessa, erilaisen tiedon hyväksymisessä ja poliittisen käytännön muuttamisessa. Luis Serra (Central American University, Nicaragua) puolestaan kuvaili osallistavaa tutkimusta sosiaaliseksi prosessiksi, joka yhdistää tutkimuksen, kasvatuksen ja sosiaalisen toiminnan. Hän esitteli esimerkinomaisesti osallistavan tutkimuksen kokeiluja Nicaraguassa. Pamela Colorado (University of Calgary), tarkasteli alkuperäisen tieteen (native science), erityisesti Amerikan intiaanien tieteen, suhdetta osallistavaan tutkimukseen. Intiaanien kulttuurin omalaatuisuus asettaa tutkimukselle aivan erilaisia vaatimuksia kuin perinteinen länsimainen kulttuuri - tunteet, historia, rukoukset, vertaukset ja suhteet ymmärretään täysin eri lähtökohdista käsin.

Toinen paneeli tarkasteli osallistavan tutkimuksen perinteiselle tutkimukselle asettamia vaatimuksia. Cynthia Nelson (American University in Cairo), kertoi tutkimusprojektistaan eräässä egyptiläisessä maalaiskylässä. Tutkijoiden ja kylän väen yhteistyö sai aikaan sekä kylän talouden että paikallisen kehittämistyön alueella merkittäviä parannuksia. Toinen puhuja Mathew Zachariah (University of Calgary) tarkasteli perinteisen tutkimuksen luotettavuudelle asettamia kriteereitä osallistavan tutkimuksen kannalta. Hän esitti, että kaikenlainen tutkimus pyrkii totuuteen ja tällöin saadun tiedon merkitystä (relevance) ja tiedon luotettavuutta (rigour) tulisi painottaa tasapuolisesti.

Kolmas paneeli tarkasteli kanadalaisia kansainvälisiä projekteja, joissa osallistavan tutkimuksen lähestymistapaa oli sovellettu. Tulevaisuus nähtiin valoisana. Pienryhmätyöskentely tuotti joukon kysymyksiä ja ristiriitoja, joita ei ehditty käytettävissä olleen ajan puitteissa käsitellä. Näihin paneudutaan lähemmein vuonna 1989 järjestettävässä konferenssissa, joka rakentuu käytännön tutkimusesimerkkien perustalle.

Kokonaisuudesaan workshop oli hengästyttävä. Aika loppui esittäjiltä kesken ja keskusteluun ei jäänyt aikaa. Osallistava tutkimus lähestymistapana tuntui kuitenkin käytännön järjestelyongelmista huolimatta soveltuvan erittäin hyvin aikuiskasvatustutkimukseen. Siinä yhdistyvät tutkimus, kasvatus ja kehittäminen kulttuurisessa kontekstissaan. Yllättävää, että suomalaiset aikuiskasvattajat eivät ole siihen enempää paneutuneet. Esimerkiksi vähemmistökulttuureihin, B-ihmisiin tai työttömiin kohdistuva tutkimus voisi saada lähestymistavasta uutta sisältöä. 
7th Annual Conference of the Canadian Association for the Study of Adult Education

Canadian Association For The Study of Adult Education järjesti seitsemännen vuotuisen konferenssinsa 4.-6. toukokuuta. Konferenssiin osallistui 201 tutkijaa ja jatko-opiskeljaa eri puolilta Kanadaa sekä tutkijoita Yhdysvalloista, Englannista, Australiasta, Skotlannista, Ruotsista, Zambiasta, Irlannista, Intiasta, Hollannista sekä Suomesta.

Kanadalainen aikuiskasvatuksen tutkimus eroaa yhdysvaltalaisesta lähinnä yhteiskunnallisemman orientaationsa kautta. Esimerkiksi suomenkävijä George van der Loos (Ladeland College), Michael Collins (University of Saskatchewan), Michael Weldon (Dailhousie University) ja Michael Law (University of British Columbia) tarkastelivat aikuiskasvatuksen yhteiskunnallista taustaa ja aikuiskasvatusta yhteiskunnallisena toimintana. Habermas, Gramsci ja Foucault muodostivat tarkastelulle perustan. Ehkäpä tämän ajattelutavan selkein voimannäyttö oli kriittisen teorian symposiumi, joka järjestettiin konferenssin lopuksi. Siinä tarkatseltiin kriittisen teorian, kriittisen kasvatuksen ja kriittisen kasvatustieteellisen tutkimuksen määritelmiä, tavoitteita ja menetelmiä. Käytännössä esitykset jäivät kuitenkin teoreettisiksi ja kantaaottaviksi, ilman riittävää kontaktia aikuiskasvatuksen käytäntöön ja konkreettiseen tutkimustyöhön.

Toinen puoli kanadalaisesta aikuiskasvatuksen tutkimuksesta tuntui noudattavan voimakkaasti empiirisen kasvatustieteen traditiota. Kvantatiivisin tutkimusmenetelmin sekä enenevässä määrin kvalitatiivisin menetelmin kerättyä tietoa esitettiin pitkälle toteavassa ja kuvailevassa muodossa. Teoreettinen tausta rakentui suurelta osin perinteisen humanistisen psykologian ja itse-ohjautuvan oppimisen (self-directed learning) perustalle. Näiltä osin tutkimus tukeutui voimakkaasti individuaaliseen ja ligeralistiseen arvomaailmaan, ollen lähinnä epäteoreettista luonteeltaan.

Kanadalainen aikuiskasvatus tuntuu olevan selkeän teoriakäytäntöristiriidan hallitsemaa. Tutkimus on joko empiiristä tai teoreettista, välimuotoja ei juurikaan esiintynyt. Toinen selkeä vastakkainasettelu oli nähtävissä perin- teisen yksilökeskeisen humanistisliberalistisen sekä yhteiskunnallisen ja yhteiskuntakriittisen arvomaailman välillä. Suomessa viimeaikoina painottunut kognitiivinen oppimisnäkemys ja sen perustalle rakennettu kasvatustieteellinen tutkimus loisti poissaolollaan.

Oma esitykseni käsitteli koulutuksen vaikuttavuutta ja sen yhteyttä työn kehittämiseen. Se oli yksi harvoista, joka suuntautui työelämän aikuiskasvatukseen. Yleisesti vaikutti siltä, että aikuiskasvatustutkimus oli painottunut vapaan sivistystyön alueelle ja työelämään suuntautuneet tutkijat olivat etsiytyneet jollekin toiselle foorumille. Havaitsin myös, että henkilöstön kehittämisen (human resource development) suuntaan oli olemassa jonkinlainen asennemuuri - HRD nähtiin pitkälle opetustek nologisista lähtökohdista tapahtuvana liiketaloudellisena toimintana.

\section{9th Annual Adult Education Re- search Conference}

29. vuotuinen Adult Education Research Conference (AERC) järjestettiin 6.-8. toukokuuta. Se lienee tunnetuin Pohjois-Amerikassa järjestettävä aikuiskasvatuksen tutkimusta käsittelevä konferenssi ja siihen osallistui 253 tutkijaa ympäri maailmaa, pääosin tosin Yhdysvalloista ja Kanadasta.

Nämä kaksi konferenssia oli yhdistetty siten, että osa esityksistä oli yhteisiä molemmille konferensseille. Näiden esitysten jälkeen syötiin yhteinen lounas, jonka yhteydessä suomalaista sukujuurta oleva John A. Niemi (Northern Illinois University), piti juhlaesitelmän. Hän tarkasteli aikuiskasvatusta maailmanlaajuisesta näkökulmasta, jolloin esimerkkimaina toimivat Suomi, Englanti, Jugoslavia ja Nigeria. Lisäksi hän tarkasteli lähemmin myös neuvostoliittolaista, kiinalaista ja yleisesti amerikkalaista aikuiskasvatusta. Hän myös painotti tutkijoiden välisen yhteydenpidon merkitystä ja tietokonekommunikaation mahdollisuuksia tällaisen kanssakäymisen edistämisessä

Konferenssin ylivoimaisesti suosituin esitys oli Jack Mezirowin (Columbia University) transformaatioteoriaa kehittelevä luento.
Osallistujia tuli niin paljon, että esitys täytyi siirtää suureen auditorioon. Luennon nostama keskustelu jatkui pitkälle yli siihen varatun ajan. Hän näki oppimisen ensi sijassa merkityksen hakemisena omista kokemuksista ja sen hyödyntämisenä päätöksenteossa ja toiminnassa. Arkitiedon (tacit knowledge) ja kommunikaation (communicative action) osuus merkitysperspektiivien (meaning perspectives) rakentamisessa on keskeinen. Näin aikuiskasvatuksen kannalta keskeiseksi muodostuu perspektiivien muovaamisen (perspective transformation) prosessi. Käytännössä tämä merkitsee kommunikatiivisen kompetenssin, kriittisen tiedostamisen ja kriittisen diskurssin merkityksen tunnustamista aikuiskasvatuksen perustavanlaatuisina lähtökohtina.

Muilta osin konferenssi jatkoi sitä edeltäneen kanadalaisen konferenssin linjoilla, paitsi että humanistis-liberalistinen ja empiirinen suuntaus oli voimakkaammin esillä, lukuunottamatta Mezirowin esitystä. Tutkimuksen lähestymistapojen pohtiminen oli myös konferenssissa keskeisemmällä sijalla. Esimerkiksi Sharan Merriam (University of Georgia) tarkasteli casestudy-menetelmää ja Sherman Stanage (Northern Illinois University) fenomenologista aikuiskasvatustutkimusta. Kvalitatiivisten tutkimusmenetelmien osuus oli esitelmissä varsin suuri. Niitä käytettiin kuitenkin lähinnä tutkimusaineiston kuvailemiseen, eikä juurikaan teoriaa luovaan tutkimustyöhön.

Pohjois-amerikkalainen aikuiskasvatustutkimus tuntuukin potevan uusien lähestymistapojen puutetta. Kvalitatiivisista tutkimusmenetelmistä ja kriittisestä teoriasta haetaan välineitä perinteisen empiristisen lähestymistavan ylittämiseksi. Toistaiseksi nämä yritykset tuntuvat tuottaneen lähinnä eräänlaisen vaihtoehtoliikkeen, jonka vetovoima perustuu vastakkainasetteluun perinteisen lähestymistavan kanssa. Lähitulevaisuudessa tarvitaan kuitenkin uusia teorian ja käytännön sekä yksilön ja yhteiskunnan yhdistäviä ajattelumalleja. Tällaisena tuntuisi palvelevan hyvin esimerkiksi neuvostopsykologian tieteentraditioon perustuva toiminnan teoria, jonka perustalle on meillä Suomessa rakennettu mm. kognitiivista didak- 
tiikkaa ja kehittävää työntutkimusta.

Kaiken kaikkiaan oli rikastuttavaa törmätä verenvähyyttä potevan suomalaisen aikuiskasvatuksen tutkijakunnan edustajana satoihin tutkijoihin muista maista. Tutkimustraditio ja tutkimuksen arvostus tuntui liikkuvan Atlantin toisella puolella aivan toisessa mittakaavassa kuin meillä. Vastaavasti meillä tutkimusseminaareihin nivoutunut tutkimuspolitiikka loisti poissaolollaan. Tutkijat kohtasivat ja paneutuivat sisällöllisesti toistensa tutkimuksiin. Keskustelu oli kriittistä ja paikoitellen rakentavaakin, pakottaen ottamaan kantaa aikuiskasvatustutkimuksen keskeisiin kysymyksiin. Vastaavanlaisten tapaamisten puuttuminen suomalaisesta aikuiskasvatuksen traditiosta tuntuukin vasta maailmalta palanneesta ahdistavalta. 